\title{
TRANSLATING DECOLONISATION
}

\section{Rodrigo Gomez*}

\author{
Rapa \\ El rugir de las olas \\ del incesante clamor \\ en aguas transparentes \\ y desordenadas \\ con despertares irreverentes \\ e inaprensibles \\ de llamadas sencillas \\ pero inmoderadas \\ y a veces cuando cansados \\ condenados a soñar \\ de ser libres \\ al fin
}

\footnotetext{
Rodrigo Gomez is a Chilean lawyer who completed a Master of Arts in Pacific Studies with Distinction at Victoria University of Wellington in 2010. The thesis was on the self-determination of the people of Rapa Nui (Easter Island). The thesis begins with this poem. It was written before the troubles in Hanga Roa of July 2010 but is well contextualised by those and more recent events on Easter Island. "Sangrienta repression en Rapa Nui" (2010) The Clinic <www.theclinic.cl>.

Translations 1, 2 and 3 are something of a team effort by Tony Angelo, Joel Colón-Ríos, John Jamieson, Talei Pasikale, and Kate Stone. The translations are endeavours to reflect the physical imagery, the sentiment and the substance of the Spanish original.

Having read the translations, the author suggested the fourth translation as that which felt "most close" to him. That translation is produced alongside the translation in te reo Māori which was made by Tai Ahu.
} 


\author{
Rapa \\ Rapa \\ The roar of waves, \\ The roar of the waves \\ the endless clamour \\ in the transparent \\ chaotic sea, \\ with irreverent and \\ unseen stirrings \\ of simple, \\ yet importunate demands, \\ at times, tiring, \\ condemned to dreams \\ of finally \\ being free. \\ of the incessant clamour \\ of waters disturbed \\ and transparent \\ with irreverent \\ and inconceivable \\ awakenings \\ of simple \\ but untempered calls \\ and sometimes when \\ wearied \\ condemned to dream \\ of being free \\ at last

\section{Rapa} \\ The roar of the waves \\ of the unceasing clamour \\ in waters transparent and in turmoil \\ with the rude and unexpected stirrings \\ of simple but untempered calls \\ and sometimes when wearied then \\ condemned to dream \\ of being free \\ at last
}


Rapa

The roar of the waves of the incessant clamour in waters disturbed and transparent with awakenings irreverent and inconceivable of calls simple but untempered and sometimes when wearied condemned to dream of being free at last
Rapa

Te wheoro o te wai karekare e pakū tonu, e pakū tonu, o te wai whakahīoi o te wai kōataata he ohonga noa, he ohonga kore kitea o te karanga haumaruru e kore e āraitia engari i tōna takawhē ka mauheretia kia moemoeā noa,

kia tukua, kia pātea kia ea 
